\title{
<シンポジウム $4>$
}

\section{7. 高血圧性脳出血急性期管理における統一した}

\section{指針に基づくチーム医療の効果}

\author{
鈴木 明文 長田 乾 川村伸悟 瀧澤 克己 佐藤 美佳 \\ 渡引康公黒崎みのり 平田 温* 安井信之** \\ 秋田県立脳血管研究七ンター・脳卒中診療部, 神経内科 *, 脳神経外科**
}

Key words : 高血圧性脳出血, 治療指針, 脳卒中チーム医療

(脳卒中 $22: 611-615,2000$ )

\section{はじめに}

高血圧性脳出血の治療についてはこれまで多くの研 究がなされてきたが, 内科系と外科系の間で議論が続 きいまだに解決されていない問題もある．大きく分け ると急性期血圧管理と手術適応の問題である. 前者は 降压に伴う灌流圧低下の危険性と降圧しない場合の血 腫増大の危険性の問題である. 妥当な血圧調節範团は いまだに決まっていない，後者については運動麻㾇な どの機能改善や昏睡例における意識回復を目的とした 手術について適応基準が明確に決まっているわけでは ない.

秋田県立脳血管研究センター（秋田脳研）では 1997 年 9 月 16 日以来, 神経内科医と脳神経外科医が脳卒中 診療部という医師チームを結成し脳出血と虚血性脳血 管障害の骖療を共同で行ってきた.チーム医療を行う に当たり過去の治療成績などを参考にして高血圧性脳 出血の治療指針を手術適応基準を含めて作成し，これ に従って診療を行ってきた。 それ以前も血腫部位, 血 腫量, 意識レベルなどに基づいて治療方針が決定され てきたが院内の共通の指針は存在せず, 診療科によっ て治療方針が異なる部分もあった。㸺卒中診療部開設 の目的には内科系と外科系で意見の異なる問題を其同 で解決することも含まれている. 現在はまだ問題解決 に至っていないが前向きの臨床研究などを進めている.

今回は我々の治療指針を紹介し，この指針に従った 治療成績を以前の成績と比較した結果を報告する。

\section{高血圧性脳出血治療指針}

表 1 に我々の治療指針を示した。現在, 高血压性脳
出血の治療指針を明確に決定できる根拠が少なく，作 成にあたっては金谷らの全国調查”の結果と我々の過 去の治療成續" を参考にした。

入院時の血圧管理については収縮期血圧 160〜140 $\mathrm{mmHg}$ を目標に降圧を図ることにした。急性期の即効 性を考えニフェジピンの舌下投与, 塩酸ジルチアゼム や塩酸ニカルジピンの静脈内投与で調節している.

被殸出血の我々の過去の治療成績2)では血腫量が 20 $\mathrm{m} l$ 以下であればほとんどの症例で薬物療法が行われ 運動麻㿎の転帰は良好であった。血腫量が $21 \mathrm{ml}$ 以上 の症例では手術療法も行われたが薬物療法の治療成績 との比較が困難であった. 手術療法による運動麻㿉改 善効果は証明されているわけではなく, 血腫が大きい ほど錐体路の直接破壊が進むため改善は困難となる. 血腫が $21 \mathrm{~m} l$ 以上の中等量である症例の中には手術 によって運動麻痺が改善した症例もみられたが, 薬物 療法で改善した症例もみられた。現在, 運動麻瘏改善 に関する問題は未解決であり, 我々はその解決を目指 して prospective studyを進めている.

脳出血の治療目標で意識障害の回復は最も重要であ る. 手術療法の適応基準は主に意識障害の回復を目的 としている．金谷らの全国調查の結果”では血腫量 30 $\mathrm{m} l$ と意識レベル混迷が薬物療法と手術療法の境界に なっている，昏睡は寝たきりになる例が多いため手術 適応がないとされている.我々はこの結果を参考にし て JCS 20 以上の意識障害例は手術療法と決めた。昏睡 例については我々の研究結果 ${ }^{3} に$ 基づいて脳幹誘発電 位の所見によって適応を決めることにしたが，現在低 体温療法の prospective study も進行しており,やや複 雑な指針となった。 
視床出血, 皮質下出血, 小脳出血, 脳幹出血につい ては大規模な調查結果もないため主に我々の経験から 指針を作成した。結果的に, JCS 10 以下，血腫量 20 $\mathrm{m} l$ 以下 (小脳出血は長径 $2 \mathrm{~cm}$ 以下) の症例と脳幹出 血のほとんどの症例は薬物療法となった。

\section{治療成績}

我々が治療指針を作成し実施したのは 1998 年 7 月 からである.そこで 1998 年 7月から 1999 年 12 月まで に入院した症例 (A 群)の治療成績を, それ以前の 1994 年 1 月から 1998 年 6 月までに入院した症例（B 群）の 治療成績と比較検討した。 A 群は 190 例, 男 108 例, 女 82 例, 平均年踰は $64 \pm 12$ 歳, B 群は 474 例, 男 271 例, 女 203 例, 平均年齢は $64 \pm 11$ 例であり, 年齢に差 はなかった. 図1に出血部位の頻度を示したＡ＼cjkstart群で 被款出血, 視床出血, 脳幹出血が若干少なく, 皮質下 出血が若干多い傾向を認めたが有意な違いはなかっ た. 図 2 に入院時意識レベルの頻度を示す. A 群で傾 眠例, 脳ヘルニア徵候を示す半昏睡例が若干多く, 混 迷, 昏睡例が若干少ない傾向を認めたが有意な違いは なかった. 図 3 に手術例の内訳と非手術例即ち薬物療 法例の頻度を示す．両群とも開頭術の頻度はほぼ同じ (A 群 6.3\%,B 群 6.5\%) であったが, 定位的血腫吸引 術は A 群で 4.7\%, B 群で 7.0\%, 脳室ドレナージ術は $\mathrm{A}$ 群で $1.1 \%$, B 群で $4.4 \%$ と A 群で頻度が少なくなっ ていた．結局 A 群では手術療法 $12.1 \%$, 薬物療法 87.9 \%, B 群では手術療法 $17.9 \%$, 薬物療法 $82.1 \%$ であり, 有意差は認めないものの治療指針を決定してから手術 療法の頻度が少なくなった。これは主に軽症例におけ
る手術が少なくなったためであった．図 4 に退院時の 日常生活能力（ADL）を示す。慢性期にリハビリテー ションが必要な症例ではリハビリテーションを開始す る前の ADL である.ADL 自立であった症例は A 群で $44.7 \%$, B 群で $37.1 \%$ であり, 有意差は認めなかったも のの A 群で自立症例の頻度が多くなっていた，ADL 非自立 (要介助), 植物状態, 死亡症例の各頻度は有意 差は認めなかったが B 群にくらべ A 群で若干少なく なっていた。

\section{考察}

これまで高血圧性脳出血の治療については多くの研 究が行われてきたが大規模な prospective study が行 われたことはなかった．最近英国で 1,000 例の登録を 目標にしたランダム化した prospective study り結果が注目されている。目本では retrospective studyではあるが金谷らによる大規模な全国調查”が 行われ，その結果をもとに被款出血については治療方 針がほぼ定められた。しかし，実際には手術適応は軽 症例, 重症例のそれぞれについて議論が続いている.

高血圧性脳出血の治療について当面解決しなければ ならない問題点として，1）急性期の妥当な血圧管理,

2）運動麻盘改善を目指す手術適応，3）昏睡例の意識 回復を目指す手術適応，4）手術による早期の意識回復 と最終的な ADLの関係, 5) 低体温療法の適応, など があげられる.これまでもこれらの問題については研 究されてきたが，ランダム化した prospective study が困難な状況もあり科学的な根拠に基づく明確な結論 を導き出すには至っていない，1）の急性期血圧管理に

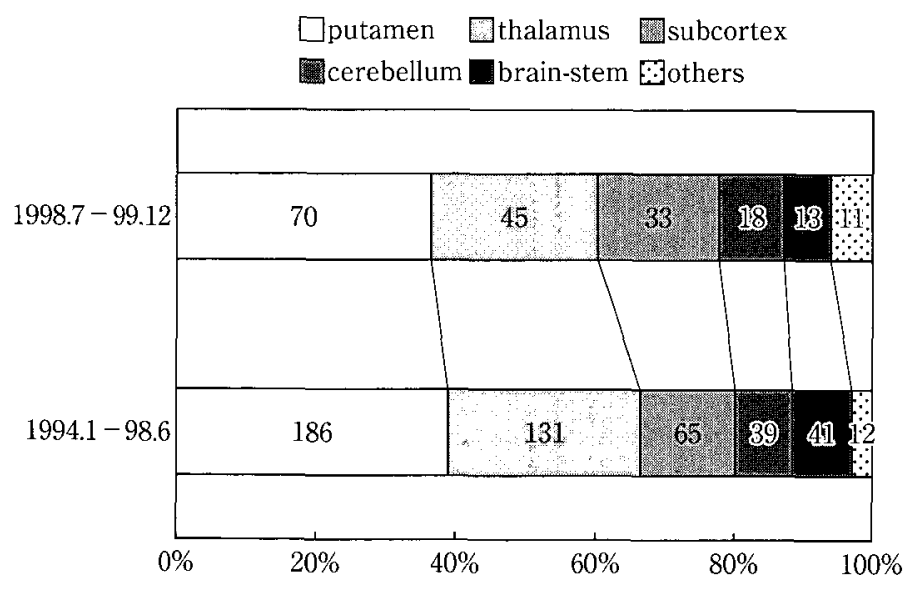

図 1 血腫部位 


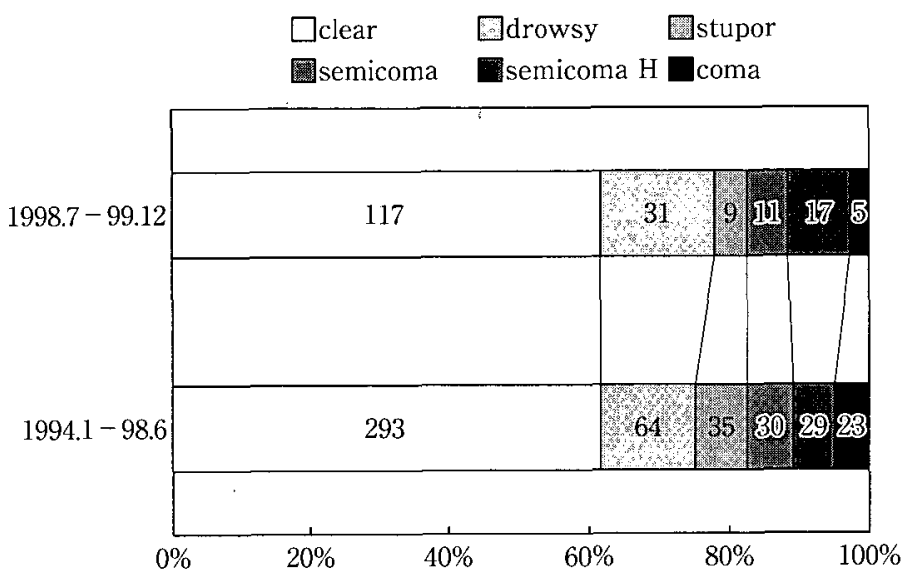

図 2 入院時意識レベル

semicoma : semicoma without herniation sign. semicoma $H$ : semicoma with herniation sign

圈craniotomy 國stereotactic $\square$ CVD $\square$ non-surgical

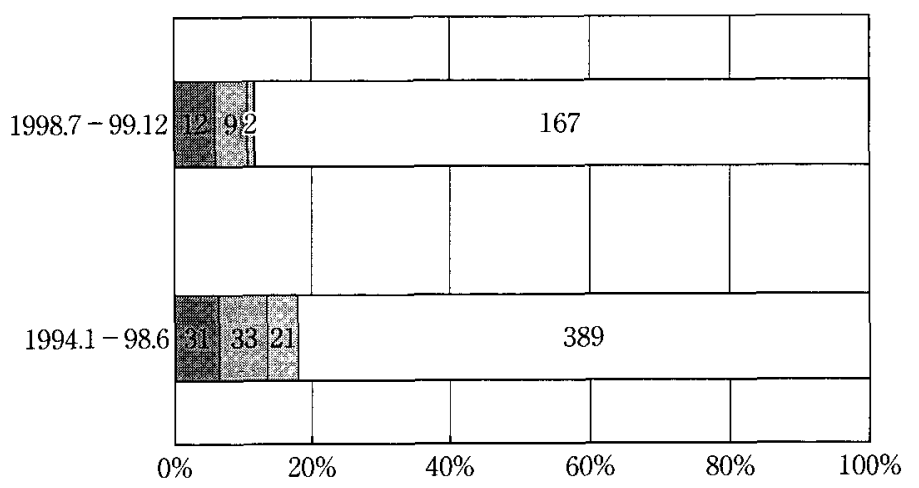

图 3 治療法

CVD : continuous ventricular drainage.

ついては再出血や血腫増大を防止するために積極的な 降圧をはかる考えと降圧に伴う脳灌流圧低下の危険性 を重視する考えがあり，明確な解決には至っていない。 我々の指針では収縮期血压 160 140 mmHgに調節す るよう定めたが，これも明らかな根捰があるわけでは ない，今回の指針による結果を基礎に今後この問題を 解決しうる方法で prospective study を計画している. 2)の手術による運動麻痺改善効果の検討については, 秋田脳研の倫理委員会の認可を得たランダム化した prospective study が進行中である.しかし, 1 施設にお ける研究の限界を感じている，3）の昏睡例の意識回復 を目指す手術適応については脳幹誘発電位が正常範囲
であれば手術でリハビリテーション可能なレベルまで 意識の回復が可能であると考えている3が，まだ経験症 例が少ない，4)の手術による早期の意識回復について は, 中等度の意識障害であっても手術によって早期に 意識の回復をはかれればリハビリテーション開始も早 期に可能であり ADL 改善につながるという考えであ る. しかし、リハビリテーション開始が荤れてもその 後時間をかければ同じレベルまで到達する可能があ る、この問題を解決するには同じ重症度の症例群でラ ンダム化した研究が必要である.5）の低体温療法の適 応については秋田脳研でも prospective study が進行 中であるが結論はまだ出ていない. 
表 1 高血圧性脳出血の治療指針

収縮期血圧を $140 〜 160 \mathrm{mmHg}$ に降圧する.

血腫量は次式で計算する[長径 $\times$ 短径 $\times$ 高さ $(\mathrm{cm})] \times 1 / 2 ，$ 小脳出血は長径は測定 $(\mathrm{cm})$

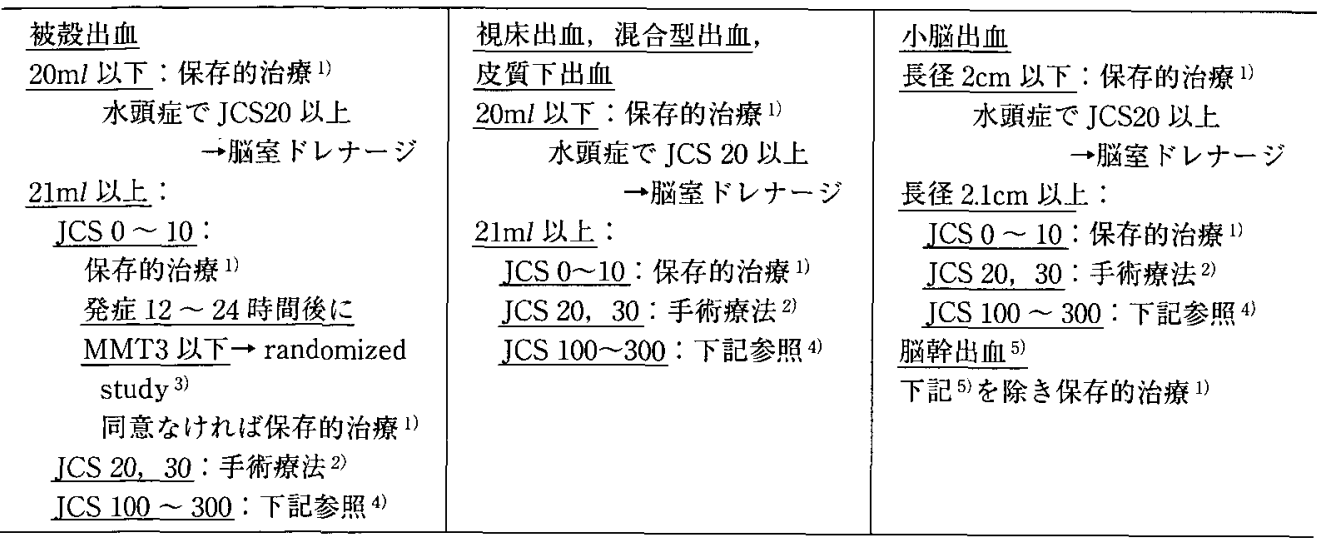

手術は 75 歳以下を原則とするが，病前の ADL，全身合併症(特に麻醉が困難な合併症の有無），physiologic age を充分検討し,インフォームド・コンセントのもとに本人·家族の希望を尊重して決定される.

1)：保存的治療としてグリセロール $400 \sim 800 \mathrm{ml}$ またはマニトール $300 \sim 600 \mathrm{~m} l / \mathrm{d}$ 血腫増大や脳浮腫でJCS 20 以上に悪化すれば手術を行う。

2）：手術燎法例は術前に脳血管撮影を行う(急激な悪化で時間的余裕なければ省略). 意識レベルが急速な悪化傾向をたどる症例，皮質下出血，小脳出血では開頭術. 水頭症がみられれば脳公ドレナージも行う。

その他は定位的血腫吸引術が発症 12 時間以降に行われる.

術後も脳浮腫がみられればグリセロール $400 〜 800 \mathrm{ml}$ またはマニトール $300 〜 600 \mathrm{ml} / \mathrm{d}$ 投与.

3）：定位的血腫吸引術の運動麻痺改善効果を検討するため封筒法による randomized study を行う.

75 歳以下，病前 ADL 自立，重篤な全身合併症がない症例でインフォームド・コンセントにより同 意を得られた症例のみ。手術は術前に脳血管撮影を行う。

保存的療法はグリセロール $400 \sim 800 \mathrm{ml}$ 投与するが血腫増大や脳浮腫で JCS20 以上に悪化すれば手 術となり研究から除外される.

4）：意識 JCS100～300では心肺系などに重篤な合併症を有しない 70 歳以下の症例ではインフォーム ド・コンセントによる同意のもとに以下の臨床研究が進行中である.

発症 6 時間以内で対光反射, 脊䯣毛様体反射, 人形の目運動のうち一つでも認めれば開頭術を行い 低体温療法. 低体温療法を行わない JCS100 300 症例では対光反射, 脊唱毛様体反射, 人形の目 運動のうち一つでも認め, 脳幹誘発電位(BSR の I , III,V波, SEP の P14,N16)が記録されれば開頭 術. 術後も脳浮腫がみられればグリセロール $400 \sim 800 \mathrm{~m} l$ またはマニトール $300 〜 600 \mathrm{~m} l / \mathrm{d}$ 投与. 对光反射, 春揈毛様体反射, 人形の目運動のいずれも認めない症例ではマニトール $600 \mathrm{~m} l$ を急速静 注して改善の有無を確認する。いずれも認めなければ通常の補液のみでみる.

5）：㮸幹背側部に限局した血腫で第 4 脳室に穿破し水頭症に対して脳室ドレナージを行ってもJCS100 以上の症例のうち, 脳幹誘発電位 $(\mathrm{BSR}$ の I, II, V波, SEP の P14, N16)が記録されれば開頭術.

治療指針の作成にあたり参考にしたのは全て retrospective studyの結果であり prospective studyの結 果はなかった. 我々の指針に従った治療成績は指針作 成以前にくらべて有意差はないものの改善傾向を示し た．現在の我々の指針に大きな間違いはないようであ るが治療指針としては未完成であり, 今後の臨床研究 の結果によっても改訂を重ねて標準的な治療指針とし て完成を目指している，治療成績の検証にはさらに症
例数の積み重ねが必要であるが，指針に従った治療を 出来るだけ忠実に行うには内科系と外科系がチーム医 療で支え合う診療体制も必要である。

\section{文献}

1）金谷春之：高血圧性脳出血の治療の現況一全国調 查の成績より一.脳卒中 $12: 509-524,1990$

2）鈴木明文, 瀧澤克己, 安井信之：高血圧性脳出血の 


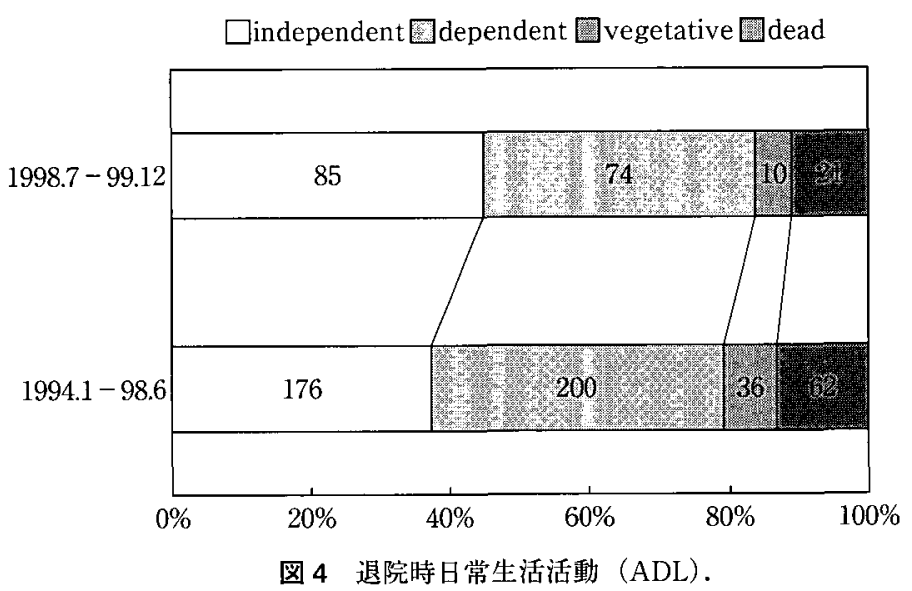

治療. 図説脳神経外科 New Approach 8 脳血管障 害 (高合公朋, 新藤 勇, 佐藤 潔, 編), 1999 , p 176-181, メジカルビュー社

3）鈴木明文, 吉岡喜美雄, 吉田貴明ら：重症脳出血手 術例に打ける脳幹誘発電位. 脳神経外科ジャーナ
ル $6: 805-812,1997$

4) Major ongoing stroke trials : Surgical trial in intracerebral haemorrhage (STICH). Stroke 30 : 490,1999

\title{
Abstract \\ Treatment of patients with hypertensive intracerebral hemorrhage according to the clinical guideline by the medical team for cerebral stroke
}

\author{
Akifumi Suzuki, M.D., Ken Nagata, M.D., Shingo Kawamura, M.D., Katsumi Takizawa, M.D., \\ Mika Sato, M.D., Yasuhito Watahiki. M.D., Minori Kurosaki, M.D., \\ Yutaka Hirata, M.D.* and Nobuyuki Yasui, M.D.** \\ Departmens of Strokology, Neurology*, Surgical Neurology**, \\ Research Institute for Brain and Blood Vessels-Akita
}

From September 1997, we organized the department of strokology which was constituted by neurologists and neurosurgeons, and started to treat stroke patients cooperatively. In July 1998, we made a clinical guidline which indicated the method of treatment for stroke patients based on retrospective studies, and started to apply clinically. According to the guidline of hypertensive intracerebral hemorrhage (HIH), the systolic blood pressure was controlled betweeen 160 and $140 \mathrm{mmHg}$ in the acute stage to prevent further bleeding. The surgical indication was restricted by both of the level of consciousness and the hematoma volume. Stuporous or semicomatose patients with intracerebral hematoma above $21 \mathrm{ml}$ or intracerebellar hematoma above $2.1 \mathrm{~cm}$ in diameter were indicated for the surgical therapy. Comatose patients with normal brain-stem evoked potentials were indicated for surgical therapy. Some comatose patients were registered to the clinical study of hypothermia therapy under the informed conscent. We evaluated the clinical outcome of patients who were applied for our clinical guidline (July 1998 December 1999), and compared to the outcome of patients who were admitted prior to the application of our guidline (January 1994 June 1998). After the introduction of our guidline, the incidence of surgical therapy was decreased from $17.9 \%$ to $12.1 \%$, and the incidence of patients who showed independent daily life on discharge was increased from $37.1 \%$ to $44.7 \%$. These differences were not significant statistically, however, the efficacy of our system for the treatment of HIH by applying the guidline in the department of strokology was suspected.

(Jpn J Stroke 22:611-615, 2000)

Key words : hypertensive intracerebral hemorrhage, clinical guidline, medical team for stroke 